\title{
Genetic Diversity and Structure of Calophyllum brasiliense Along the Santa Catarina Coast
}

\author{
Fernando André Loch Santos da Silva ${ }^{1}$ (D), \\ Tiago Montagna $^{2}$ (D), Miguel Busarello Lauterjung ${ }^{2}$ (D), Ricardo Bittencourt ${ }^{3}$ (D), \\ Maurício Sedrez dos Reis ${ }^{2}$
}

${ }^{1}$ Loch Representações Agrícolas LTDA, Palhoça/SC, Brasil

${ }^{2}$ Núcleo de Pesquisas em Florestas Tropicais, Departamento de Fitotecnia, Centro de Ciências Agrárias, Universidade Federal de Santa Catarina - USFC, Florianópolis/SC, Brasil

${ }^{3}$ Departamento de Ciências Naturais, Fundação Universidade Regional de Blumenau - FURB, Blumenau/SC, Brasil

\begin{abstract}
Population genetics studies can provide knowledge in support of conservation efforts for plant populations. We studied the genetic diversity and structure in nine populations of Calophyllum brasiliense from Santa Catarina state, Brazil, aiming to establish conservation strategies. Allozymic markers were used to genotype about 50 individuals from each population. Moderate genetic diversity (mean $=0.135)$ and high fixation indexes $($ mean $=0.259)$ were estimated. Genetic divergence was significant, equal to 0.140 , and a Bayesian analysis found two different genetic groupings. The results show clear signs of risk of diversity loss, basically related to restrictions of effective size. As conservation efforts, we suggested the use of $C$. brasiliense in restoration programs and for wood production. We also suggested the protection of its associated fauna and the development of more protected areas. Finally, populations 430, 640, 642 and 913 were indicated as priorities for conservation, based on their genetic indexes.
\end{abstract}

Keywords: conservation, effective size, olandi, quaternary coastal plains. 


\section{INTRODUCTION}

Population genetics studies allow us to understand the origin, amount, and distribution of genetic variation present in populations of organisms, as well as its spatiotemporal variation (Templeton, 2011). This, in turn, forms a foundation for understanding the consequences of anthropic actions on populations (e.g., Hall et al., 1996; Bittencourt \& Sebbenn, 2009; Silva \& Reis, 2010) and proposing conservation strategies for populations at risk (e.g., Hmeljevski et al., 2011; Ferreira et al., 2012; Rogalski et al., 2017). Studies proposing conservation efforts for plant populations commonly use molecular markers to investigate genetic diversity and structure (e.g., Botrel et al., 2006; Reis et al., 2009; Nazareno \& Reis, 2014).

Calophyllum brasiliense Cambess. (Clusiaceae), popularly known as olandi or guanandi, is a tree species with wide natural occurrence area, from latitude $18^{\circ} \mathrm{N}$ in Costa Rica, to $28^{\circ} 10^{\prime} \mathrm{S}$ in Brazil (Carvalho, 2003). It occurs in distinct biomes along Brazil (Cerrado, Amazon and Atlantic Forests and Restinga), and in Santa Catarina state (SC), its occurrence is restricted to the quaternary coastal plains where it is one of the dominant species (Klein, 1978; Lingner et al, 2013). Calophyllum brasiliense occurs in soils with poor drainage and in an area further characterized by humidity and periodic flooding (Reitz et al., 1978; Carvalho, 2003). Forests occurring on quaternary coastal plains are subject to flooding and thus commonly termed as caixetais or olandizais, owing to the dominance of Tabebuia cassinoides (caixeta) and C. brasiliense (olandi) (Reitz et al., 1978; Galvão et al., 2002).

Forests of the quaternary coastal plains, collectively called restinga, exhibit distinct vegetation forms, ranging from grasslands with predominance of herbaceous plants to scrubs and forest physiognomies (Marques et al., 2015). In SC, these forests are threatened by real estate speculation and silvopastoral activities (Reis et al., 2012; Schultz, 2012; Lingner et al., 2013); moreover, C. brasiliense is considered endangered in SC, having been categorized as critically endangered (Santa Catarina, 2014). This calls for studies to support conservation strategies for this species and its habitat. Other studies have also pointed to the need for conservation actions for ecosystems in quaternary coastal plains (Scarano, 2006; Reis et al., 2012; Marques et al., 2015).
Thus, the present study explored the genetic diversity and structure of $C$. brasiliense populations, aiming to establish conservation strategies for the species and its habitat in SC. This study is part of the project entitled "Floristic and Forest Inventory of Santa Catarina", from which the objective is to evaluate forest remnants of SC in order to form a basis for proposing public conservation policies directed toward the forestry sector (Vibrans et al., 2012).

\section{MATERIAL AND METHODS}

\subsection{Sampling and genotyping}

Fresh leaves of approximately 50 adult individuals, spaced at least $50 \mathrm{~m}$ apart, were collected in nine populations along the area of occurrence of $C$. brasiliense in SC (Figure 1). The samples were kept refrigerated until the time of genotyping.

To assess the genetic diversity levels of the populations, we used allozymic markers, resolved and stained in maize starch gel (13\%), according to the recommendations of Kephart (1990) and Alfenas (1998). Tris-Citrate buffer pH 7.5 (Tris $27 \mathrm{~g} / \mathrm{l}$ and citric acid $16.52 \mathrm{~g} / \mathrm{l}$ ) was used to solve the following allozymic systems: 6-phosphogluconate dehydrogenase (6PGDH, Enzyme Commission 1.1.1.44), diaphorase (DIA, EC 1.8.1.4), glutamate oxalacetate transaminase (GOT, EC 2.6.1.1), isocitrate dehydrogenase (HDI, EC 1.1.1.42), malic enzyme ME, EC 1.1.1.40), malate dehydrogenase (MDH, EC 1.1.1.37), phosphoglucoisomerase (PGI, EC 5.3.1.9), phosphoglucomutase (PGM, EC 5.4.2.2), peroxidase (PO, EC 1.11.1.7), and shikimate dehydrogenase (SKDH, EC 1.1.1.25), totaling 10 systems.

\subsection{Data analysis}

Based on genotypes observed in gel, we estimated the allelic frequencies, percentage of polymorphic loci $(\hat{P})$, number of alleles $(\hat{k})$, average number of alleles per locus $(\hat{A})$, number of rare $\left(\hat{A}_{r}-\right.$ frequency $\left.<5 \%\right)$ and private alleles ( $\hat{A}_{e x}$ - occuring in only one population), observed heterozygosity $\left(\hat{H}_{O}\right)$, expected heterozygosity under Hardy Weinberg Equilibrium $\left(\hat{H}_{E}\right)(\mathrm{Nei}, 1973)$, and the fixation index $(\hat{f})$ for each studied population. The genetic divergence between populations $(\hat{\theta})$ was estimated as proposed by Weir $\&$ Cockerham (1984). Statistical significance $(\mathrm{p}<0.05)$ 


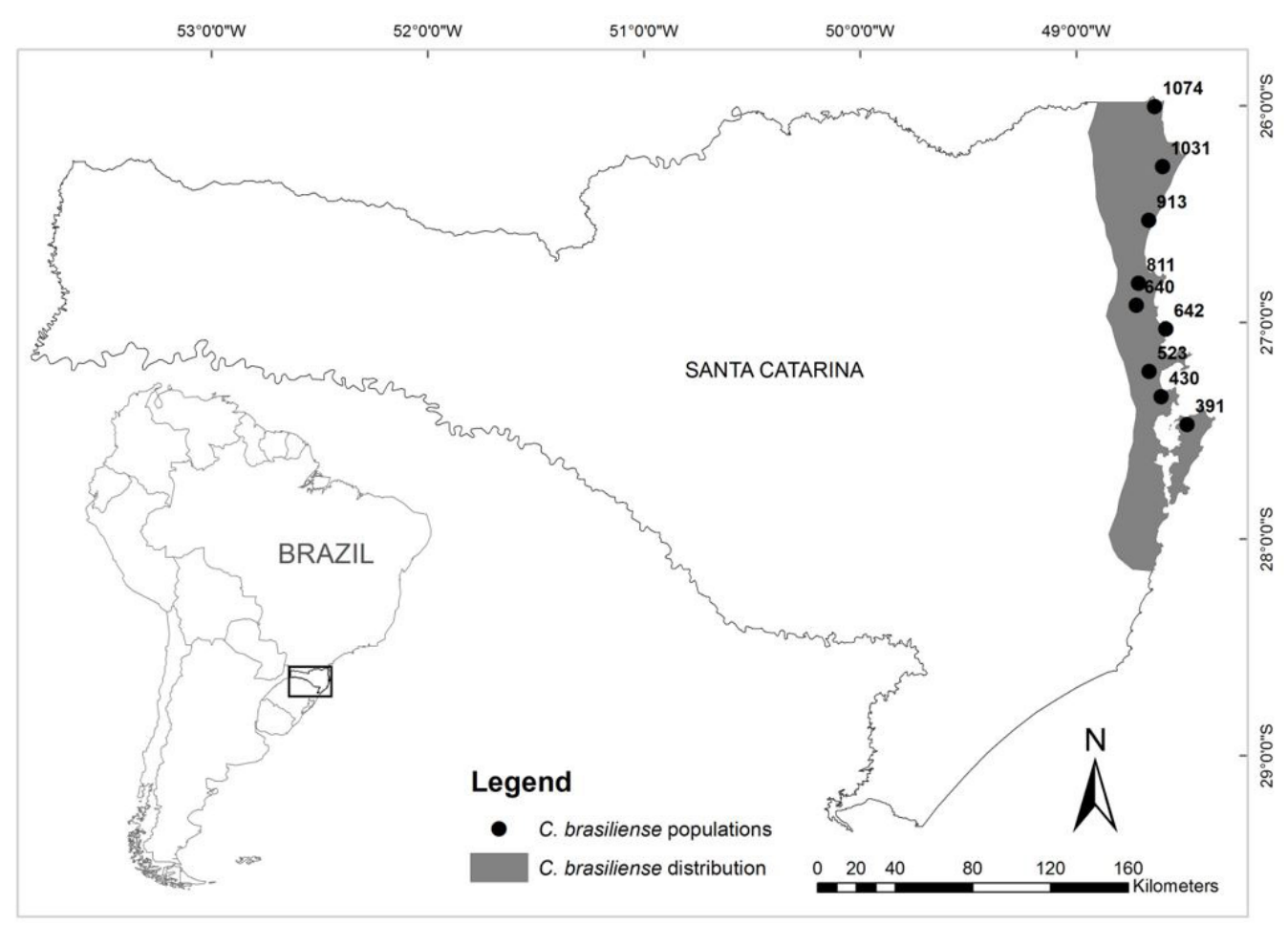

Figure 1. Map of nine sampled populations (dots) of Calophyllum brasiliense in Santa Catarina state, Brazil. Coloring represents the occurrence area of Calophyllum brasilense Cambess. (Reitz et al., 1978).

for $\hat{f}$ values was obtained by permutations of alleles between individuals and within populations, and for $\hat{\theta}$ values, by 1,000 bootstraps between loci. Effective size $\left(\hat{N}_{e}\right)$ was estimated using Equation 1, as proposed by Li (1976). Except for $\hat{N}_{e}$, all other estimates were calculated using FSTAT, version 2.9.3.2 (Goudet, 2002).

$\hat{N}_{e}=n /(1+\hat{f})$

where: $n=$ sample size and $\hat{f}=$ fixation index.

Based on the $\hat{N}_{e}$ of each population, we estimated the minimum numbers of seed trees to be sampled in the event of seed collection to establish new populations with effective sizes of 25,50 and 500 , as proposed by Sebbenn (2002). Therefore, the ratio between the sample size $(n)$ and the $\hat{N}_{e}$ of each population was multiplied by 25,50 and 500 .

To assist in the identification of priority conservation areas, a Bayesian analysis of the genetic structure was conducted, aiming to estimate an optimal number of populations to conserve, depending on the number of genetic groups $(K)$, using STRUCTURE, version 2.3.4 (Pritchard et al., 2000). The analysis was performed under the admixture model with correlated allele frequencies, with 50,000 burn-in length periods and 100,000 Markov chain Monte Carlo replications. Each run was iterated 10 times, with $K$ ranging from 1 to 9 . The most probable value of $K$ was selected using the highest value of $\Delta K$ (Evanno et al., 2005) in the STRUCTURE HARVESTER program (Earl \& vonHoldt, 2012).

A Mantel test (Mantel, 1967) was conducted in order to identify if geographical distances $(\mathrm{km})$ influence the levels of genetic divergence $(\hat{\theta})$. Thus, a Pearson correlation was estimated between the pairwise geographic distances and genetic divergences between populations with both distances transformed $[\log (k m)] \sim[\hat{\theta} /(1-\hat{\theta})]$, according to Rousset (1997). Statistical significance $(\mathrm{p}<0.05)$ for the correlation was obtained using a $t$ test (Equation 2).

$t=r \sqrt{\left(n-2 / 1-r^{2}\right)}$

where: $r=$ Pearson correlation coefficient and $n=$ number of populations pairs. 


\section{RESULTS}

\subsection{Genetic diversity}

The 10 allozymic systems allowed the interpretation of 14 loci, of which nine were polymorphic. The allelic frequencies (Table 1) within each polymorphic locus were mostly concentrated in only one of the alleles, a fact that reduced the estimates of $\hat{H}_{E}$. Thirty distinct alleles were identified among the nine populations, out of which three were private: alleles 6PGDH-2-3 and $\mathrm{PO}-2-3$ in population 391, and allele DIA-3-1 in population 640 (Table 1).

The estimated genetic diversity indexes for the studied populations are shown in Table 2. All populations presented at least one rare allele $\left(\hat{A}_{r}\right)$. Estimates of $\hat{H}_{O}$ were lower than $\hat{H}_{E}$ for all populations, resulting in positive and significant fixation indexes. Consequently, the estimated effective sizes $\left(\hat{N}_{e}\right)$ were always smaller than the sample sizes, reflecting the estimated $\hat{f}$ for each population (Table 2).

Table 1. Allelic frequencies for nine populations of Calophyllum brasilense Cambess. using 14 allozymic loci.

\begin{tabular}{|c|c|c|c|c|c|c|c|c|c|c|c|}
\hline Locus & Allele & 391 & 430 & 523 & 642 & 640 & 811 & 913 & 1031 & 1074 & All \\
\hline \multirow{2}{*}{ 6PGDH-1 } & 1 & 0.971 & 0.981 & 0.962 & NE & 1 & 0.981 & 0.419 & 0.99 & 0.962 & 0.934 \\
\hline & 2 & 0.029 & 0.019 & 0.038 & NE & 0 & 0.019 & 0.581 & 0.01 & 0.038 & 0.066 \\
\hline \multirow{3}{*}{ 6PGDH-2 } & 1 & 0.048 & 0.115 & 0.009 & $\mathrm{NE}$ & 0.333 & 0.096 & 0.984 & 0.188 & 0.03 & 0.185 \\
\hline & 2 & 0.952 & 0.865 & 0.991 & NE & 0.667 & 0.904 & 0.016 & 0.813 & 0.97 & 0.812 \\
\hline & 3 & 0 & 0.019 & 0 & $\mathrm{NE}$ & 0 & 0 & 0 & 0 & 0 & 0.003 \\
\hline DIA-1 & 1 & 1 & 1 & 1 & 1 & 1 & 1 & 1 & 1 & 1 & 1 \\
\hline DIA-2 & 1 & 1 & 1 & 1 & 1 & 1 & 1 & 1 & 1 & 1 & 1 \\
\hline \multirow{3}{*}{ DIA-3 } & 1 & 0 & 0 & 0 & 0 & 0.058 & 0 & 0 & 0 & 0 & 0.006 \\
\hline & 2 & 0.865 & 0.824 & 0.925 & 1 & 0.913 & 1 & 1 & 1 & 1 & 0.948 \\
\hline & 3 & 0.135 & 0.176 & 0.075 & 0 & 0.029 & 0 & 0 & 0 & 0 & 0.046 \\
\hline GOT & 1 & 1 & 1 & 1 & 1 & 1 & 1 & 1 & 1 & 1 & 1 \\
\hline \multirow{2}{*}{ IDH } & 1 & 0 & 0 & 0.047 & 0 & 0 & 0 & 0 & 0 & 0.019 & 0.007 \\
\hline & 2 & 1 & 1 & 0.953 & 1 & 1 & 1 & 1 & 1 & 0.981 & 0.993 \\
\hline $\mathrm{ME}$ & 1 & 1 & 1 & 1 & 1 & 1 & 1 & 1 & 1 & 1 & 1 \\
\hline \multirow{3}{*}{ MDH-1 } & 1 & 0.077 & 0.147 & 0.269 & 0.167 & 0.102 & 0.329 & 0.135 & 0.208 & 0.16 & 0.173 \\
\hline & 2 & 0.038 & 0.118 & 0.038 & 0.069 & 0.046 & 0 & 0.115 & 0.047 & 0.06 & 0.06 \\
\hline & 3 & 0.885 & 0.735 & 0.692 & 0.765 & 0.852 & 0.671 & 0.75 & 0.745 & 0.78 & 0.766 \\
\hline MDH-2 & 1 & 1 & 1 & 1 & 1 & 1 & 1 & 1 & 1 & 1 & 1 \\
\hline \multirow{3}{*}{ PGI-2 } & 1 & 0.788 & 0.683 & 0.698 & 0.88 & 0.676 & 0.873 & 0.935 & 0.877 & 0.863 & 0.805 \\
\hline & 2 & 0.192 & 0.317 & 0.302 & 0.12 & 0.287 & 0.127 & 0.043 & 0.123 & 0.137 & 0.187 \\
\hline & 3 & 0.019 & 0 & 0 & 0 & 0.037 & 0 & 0.022 & 0 & 0 & 0.009 \\
\hline \multirow{3}{*}{ PGM } & 1 & 0 & 0 & 0.023 & 0.133 & 0.113 & 0.365 & 0.302 & 0.031 & 0.054 & 0.112 \\
\hline & 2 & 0.442 & 0.547 & 0.398 & 0.337 & 0.226 & 0 & 0.417 & 0.5 & 0.489 & 0.373 \\
\hline & 3 & 0.558 & 0.453 & 0.58 & 0.531 & 0.66 & 0.635 & 0.281 & 0.469 & 0.457 & 0.515 \\
\hline \multirow{3}{*}{ PO-2 } & 1 & 0.01 & 0.01 & 0 & 0 & 0 & 0 & 0 & 0 & 0 & 0.002 \\
\hline & 2 & 0.99 & 0.95 & 1 & 1 & 1 & 1 & 1 & 1 & 1 & 0.994 \\
\hline & 3 & 0 & 0.04 & 0 & 0 & 0 & 0 & 0 & 0 & 0 & 0.004 \\
\hline \multirow{3}{*}{ SKDH } & 1 & 0.721 & 0.721 & 0.761 & 0.806 & 1 & 0.814 & 0.73 & 0.802 & 1 & 0.82 \\
\hline & 2 & 0.279 & 0.269 & 0.239 & 0.153 & 0 & 0.186 & 0.24 & 0.151 & 0 & 0.167 \\
\hline & 3 & 0 & 0.01 & 0 & 0.041 & 0 & 0 & 0.03 & 0.047 & 0 & 0.013 \\
\hline
\end{tabular}

$\mathrm{NE}=$ not evaluated 
Table 2. Population genetics estimates for nine Calophyllum brasilense Cambess. populations sampled in Santa Catarina state, Brazil.

\begin{tabular}{cccccccccccc} 
Population & $n$ & $\hat{N}_{e}$ & $\hat{P}$ & $\hat{k}$ & $\hat{A}$ & $\hat{A}_{r}$ & $\hat{A}_{e x}$ & $\hat{H}_{E}$ & $\hat{H}_{O}$ & $\hat{f}$ \\
\hline 391 & 52 & 42 & 0.57 & 24 & 1.71 & 5 & 0 & 0.133 & 0.102 & $0.238^{*}$ \\
430 & 52 & 42 & 0.57 & 26 & 1.86 & 5 & 2 & 0.175 & 0.136 & $0.226^{*}$ \\
523 & 52 & 42 & 0.57 & 24 & 1.71 & 5 & 0 & 0.149 & 0.112 & $0.246^{*}$ \\
642 & 51 & 35 & 0.43 & 21 & 1.58 & 1 & 0 & 0.127 & 0.072 & $0.437^{*}$ \\
640 & 54 & 38 & 0.36 & 23 & 1.64 & 3 & 1 & 0.132 & 0.080 & $0.392^{*}$ \\
811 & 51 & 41 & 0.43 & 20 & 1.43 & 1 & 0 & 0.119 & 0.091 & $0.234^{*}$ \\
913 & 48 & 40 & 0.43 & 24 & 1.71 & 4 & 0 & 0.153 & 0.123 & $0.197^{*}$ \\
1031 & 51 & 43 & 0.43 & 23 & 1.64 & 4 & 0 & 0.130 & 0.105 & $0.193^{*}$ \\
1074 & 51 & 44 & 0.43 & 22 & 1.57 & 3 & 0 & 0.095 & 0.079 & $0.168^{*}$ \\
Average & 51 & 41 & 0.47 & 23 & 1.65 & - & - & 0.135 & 0.100 & 0.259 \\
All & 454 & 335 & 0.64 & 30 & 2.14 & - & - & 0.153 & 0.099 & 0.354 \\
\hline
\end{tabular}

$n$ = sample size; $\hat{N}_{e}=$ effective size; $\hat{P}=$ percentage of polymorphic loci; $\hat{k}=$ number of alleles; $\hat{A}$ = average number of alleles per locus; $\hat{A}_{r}=$ number of rare alleles; $\hat{A}_{e x}=$ number of private alleles; $\hat{H}_{E}=$ genetic diversity; $\hat{H}_{O}=$ observed heterozygosity; $\hat{f}=$ fixation index; ${ }^{*} \mathrm{p}<0.05$.

\subsection{Genetic structure}

Populations exhibited significant genetic divergence $(\hat{\theta})$, equal to 0.140 . The Mantel test presented a non-significant correlation of 0.08 between genetic divergence and geographic distances. Bayesian analysis returned an ideal number of genetic groupings $(K)$ equal to 2 (Figures 2 and 3 ).

\section{DISCUSSION}

\subsection{Genetic diversity}

The presence of fixed loci (Table 1) suggests loss of alleles from genetic drift. The diversity indexes found by the present study were lower than the averages compiled by Hamrick \& Godt (1989) for long-lived tree species (Table 3 ). The same trend was observed when our results were compared to indexes estimated by studies with other populations of $C$. brasilense (Table 3). Also noteworthy is the fact that most studies with populations of $C$. brasilense estimated lower $\hat{f}$ per population than those estimated by the present study (Table 3).

The fact that all studied populations presented rare alleles, more susceptible to the effects of genetic drift, and high $\hat{f}$, owing to significant deviations between $\hat{H}_{O}$ and $\hat{H}_{E}$, shows that the populations of $C$. brasilense risk the loss of diversity in the next generations. These findings may result from aspects related to the mating

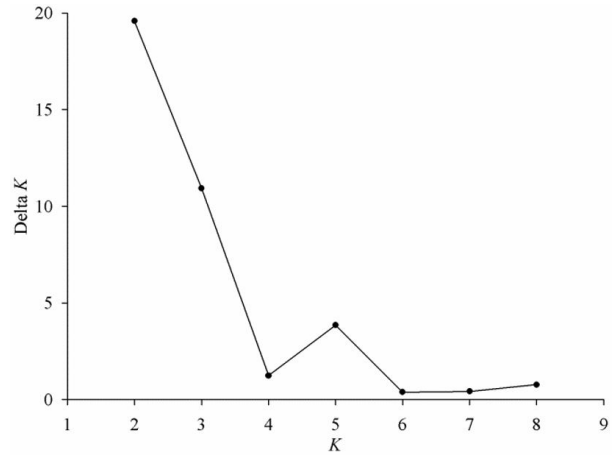

Figure 2. Ideal number of genetic clusters $(K)$ according to $\Delta K$ (Evanno et al., 2005) for nine Calophyllum brasilense Cambess. populations.

system of the species or to historical population reduction caused by exploitation and fragmentation.

It is not yet known if $C$. brasiliense presents an outcrossed, autogamous or mixed mating system. The species is pollinated by bees of the Halictidae family (Fischer \& Santos, 2001), which indicates at least a tendency for cross-fertilization. However, C. brasiliense presents hermaphrodite and male flowers in separate individuals, or in different proportions in the same individual (Fischer \& Santos, 2001; Botrel et al., 2006), and that can be a sign of some level of autogamy. Tree species with an outcrossed system have higher diversity indexes within species and populations than species with mixed or autogamous systems (Hamrick et al., 1992). Therefore, the mating system of a species can help to explain the genetic indexes. 


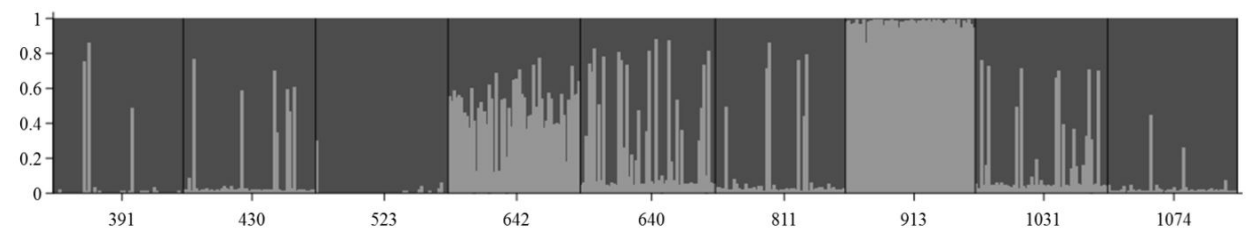

Figure 3. Assignation of individuals to genetic clusters when $K=2$ for nine Calophyllum brasilense Cambess. populations. The color in each barplot represents the probability of each individual belonging to a genetic cluster.

Table 3. Comparison of the mean indexes of genetic diversity obtained in the present study with other studies.

\begin{tabular}{cccccc}
\hline Study & Pop. & $\hat{A}$ & $\hat{H}_{E}$ & $\hat{H}_{O}$ & $\hat{f}$ \\
\hline Hamrick \& Godt $(1989)^{\dagger}$ & 115 & $1.79 \uparrow$ & $0.149 \uparrow$ & $\mathrm{NE}$ & $\mathrm{NE}$ \\
\hline Kawaguici \& Kageyama $(2001)^{\dagger \dagger}$ & 1 & $1.64 \downarrow$ & $0.223 \uparrow$ & $0.141 \uparrow$ & $0.372 \uparrow$ \\
\hline Botrel et al. $(2006)^{\dagger \dagger}$ & 2 & $1.75 \uparrow$ & $0.131 \downarrow$ & $0.119 \uparrow$ & $0.091 \downarrow$ \\
\hline Souza et al. $(2007)^{\mathrm{H}}$ & & $1.5 \downarrow$ & $0.112 \downarrow$ & $0.111 \uparrow$ & $0.008 \downarrow$ \\
\hline Reis et al. $(2009)^{\mathrm{\dagger t}}$ & 2 & $2.00 \uparrow$ & $0.430 \uparrow$ & $0.444 \uparrow$ & $-0.031 \downarrow$ \\
Present study & 1 & $2.00 \uparrow$ & $0.438 \uparrow$ & $0.492 \uparrow$ & $-0.125 \downarrow$ \\
\hline
\end{tabular}

Higher $(\uparrow)$ or lower $(\downarrow)$ index when compared to the same index estimated in the present study. Pop. = number of sampled populations; $\hat{A}=$ average number of alleles per locus; $\hat{H}_{E}=$ genetic diversity; $\hat{H}_{O}=$ observed heterozygosity; $\hat{f}=$ fixation index; ${ }^{\dagger}$ compilation of 115 populations of tropical species; ${ }^{\text {t }}$ studies with populations of Calophyllum brasilense Cambess; $\mathrm{NE}=$ not evaluated

Accordingly, this question needs to be evaluated in more depth for C. brasiliense in order to make more accurate inferences about its conservation status and also to better design strategies to conserve the genetic diversity of the species in remnant populations.

On the other hand, even in the absence of specific estimates, forests of the Brazilian coastal plains are highly fragmentated (Marques et al., 2015). In addition, populations of $C$. brasiliense went through the logging process at different levels of intensity. Reitz et al. (1978) have already pointed out the rarity of the species, even in its occurrence area in SC, and later, Marques \& Joly (2000) reported that populations of C. brasiliense were under heavy pressure from illegal logging and/or the advance of agricultural areas.

Fragmentation and exploitation events act to isolate and diminish populations, respectively. As a consequence, populations are more susceptible to the effects of genetic drift and, in the long term, they may present an increase in fixation indexes owing to the increased frequency of crosses between related individuals (Ellstrand \& Elam, 1993; Kageyama et al., 1998) and the absence of gene flow. Thus, the estimated fixation indexes for the studied populations may be related to the history of environmental fragmentation and exploration, as reported for the quaternary coastal plains and for C. brasiliense, respectively. Effects of fixation indexes are already perceived in $\hat{N}_{e}$ estimates, which were, on average, $20 \%$ smaller than the sample sizes.

\subsection{Genetic structure}

The estimation of genetic divergence $(\hat{\theta})$ indicates that $14 \%$ of the genetic diversity is not shared by the populations, and although the most distant populations are approximately $160 \mathrm{~km}$ apart, geographic distance did not significantly influence genetic divergence, as evidenced by the Mantel test. This result indicates that events of fragmentation and exploitation, or even founder effects, are more important for the generation 
of genetic structure than geographic distance between populations.

Bayesian analysis of the genetic structure demonstrated the existence of two distinct genetic groups, one formed by populations 642 and 913, and the other formed by the other populations (Figure 3 ). This clustering is useful for determining priority populations for conservation based on the genetic structure because it demonstrates which populations present significant distinct genetic compositions. Therefore, aiming to conserve the greatest amount of genetic diversity with the lowest number of populations, we should choose at least one population from each group.

\subsection{Conservation of genetic diversity}

The results show that the populations of C. brasiliense risk the loss of diversity related to restrictions of effective size, as imposed by the habitats' exploitation and fragmentation history. Therefore, the suggestion of conservation measures should take this into account. However, questions linked to the mating system cannot be discounted (e.g., possible levels of autogamy).

Increasing gene flow among populations can mitigate the effects of genetic drift and high fixation indexes. This could be accomplished by including this species in reforestation programs, taking advantage of its tolerance to poor drainage, humidity and periodic flooding (Reitz et al., 1978; Carvalho, 2003; Oliveira \& Joly, 2010), as well as its interaction with fauna (Fischer \& Santos, 2001; Carvalho, 2003). Other authors have also pointed out this possibility (Oliveira \& Joly, 2010; Schultz, 2012).
We know that the mating system in relation to fauna plays an important role in gene flow between and within populations of $C$. brasiliense, especially since flowers are pollinated by bees (Fischer \& Santos, 2001), and fruits are dispersed by bats (Phyllostomidae) and birds, such as Cyanocorax caeruleus (Fischer \& Santos, 2001; Carvalho, 2003). Hence, the preservation of fauna is important to the maintenance of $C$. brasiliense gene flow, especially in fragmented areas of quaternary coastal plains (Marques et al., 2015).

Calophyllum brasiliense presents high-quality wood in addition to its moderate growth (Carvalho, 2003). Consequently, the establishment of plantations for wood production could be a viable alternative to increase $C$. brasiliense populations and the connectivity between them, even if they are temporary. Thus, with the adoption of seed collection criteria, forest fragments could serve as a source of seeds for local plantations.

Sebbenn (2002) recommends the collection of seeds in 25 seed trees, aiming to establish reforestation of less than 100 ha, in 40 to 50 seed trees for reforestation with an area between 100 and 500 ha, and in 400 to 500 seed trees for establishing reforestation in areas larger than 500 ha. However, since all populations presented high $\hat{f}$ (Table 2 ), the number of seed trees collected should be, correspondingly, higher, as shown in Table 4.

Based on Bayesian analysis of genetic structure and on the genetic diversity estimates, populations 430, 640, 642 and 913 are indicated as priorities for conservation. The first two have private alleles (Table 2) and are part of a distinct genetic grouping from the last two, which, in turn, are the most genetically distinct populations (Figure 3).

Table 4. Number of seed trees required for seed collection aiming at an effective size of $25\left(\hat{N}_{e}=25\right), 50\left(\hat{N}_{e}=50\right)$ and $500\left(\hat{N}_{e}=500\right)$.

\begin{tabular}{|c|c|c|c|c|c|c|}
\hline Population & $n$ & $\hat{N}_{e}$ & $\mathbf{n} / \hat{N}_{e}$ & $\hat{N}_{e}=25$ & $\hat{N}_{e}=\mathbf{5 0}$ & $\hat{N}_{e}=500$ \\
\hline 391 & 52 & 42 & 1.24 & 31 & 62 & 619 \\
\hline 430 & 52 & 42 & 1.23 & 31 & 61 & 613 \\
\hline 523 & 52 & 42 & 1.25 & 31 & 62 & 623 \\
\hline 642 & 51 & 35 & 1.44 & 36 & 72 & 719 \\
\hline 640 & 54 & 38 & 1.39 & 35 & 70 & 696 \\
\hline 811 & 51 & 41 & 1.23 & 31 & 62 & 617 \\
\hline 913 & 48 & 40 & 1.20 & 30 & 60 & 599 \\
\hline 1031 & 51 & 43 & 1.19 & 30 & 60 & 597 \\
\hline 1074 & 51 & 44 & 1.17 & 29 & 58 & 584 \\
\hline
\end{tabular}

$n=$ sample size; $\hat{N}_{e}=$ effective size. 


\section{CONCLUSION}

The Calophyllum brasiliense populations studied had, in general, lower genetic diversity than expected for a long-lived tree species, along with high fixation indexes, implying constraints in effective size in the past. This condition plus the contemporary habitat fragmentation endangers the maintenance of genetic diversity of the species, putting specially the rare alleles, which were sampled in all populations, at risk of loss.

Conservation efforts should involve expanding populations and increasing connectivity between them. Therefore, we suggest the following conservation strategies: 1) the use of C. brasiliense in restoration programs of degraded areas; 2) the establishment of plantations with $C$. brasiliense for wood production; 3 ) the protection of the fauna associated with C. brasiliense; and 4 ) the inclusion of more fragments of quaternary coastal plains in protected areas.

Populations 430, 640, 642 and 913 are indicated as priorities for conservation. The first two represent the presence of private alleles (Table 2), and the last two represent the most genetically distinct (Figure 3 ). For a better understanding of the factors influencing the levels of genetic diversity between and within populations, studies to elucidate the mating system of the species are crucial.

\section{ACKNOWLEDGEMENTS}

We would like to thank the Núcleo de Pesquisas em Florestas Tropicais (NPFT) and the Laboratório de Fisiologia do Desenvolvimento e Genética Vegetal (LFDGV) research groups for logistical support.

\section{SUBMISSION STATUS}

Received: 26 july, 2017

Accepted: 6 apr., 2018

\section{CORRESPONDENCE TO}

\section{Maurício Sedrez dos Reis}

Núcleo de Pesquisas em Florestas Tropicais, Departamento de Fitotecnia, Centro de Ciências Agrárias, Universidade Federal de Santa Catarina - UFSC, Rodovia Admar Gonzaga, 1346, CEP 88034-200, Florianópolis, SC, Brasil e-mail: msedrez@gmail.com

\section{FINANCIAL SUPPORT}

Conselho Nacional de Desenvolvimento Científico e Tecnológico (Grant/Award Number: '309128/2014-5'); Coordenação de Aperfeiçoamento de Pessoal de Nível Superior; Fundação de Amparo à Pesquisa e Inovação do Estado de Santa Catarina (Grant/Award Number: '11939/2009').

\section{REFERENCES}

Alfenas AC. Eletroforese de isoenzimas e proteínas afins: fundamentos e aplicações em plantas e microorganismos. Viçosa: Editora Universidade Federal de Viçosa; 1998.

Bittencourt JVM, Sebbenn AM. Genetic effects of forest fragmentation in high-density Araucaria angustifolia populations in Southern Brazil. Tree Genetics \& Genomes 2009; 5(4): 573-582. http://dx.doi.org/10.1007/s11295009-0210-4.

Botrel MCG, Souza AM, Carvalho D, Pinto SIC, Moura MCO, Estopa RA. Caracterização genética de Calophyllum brasiliense Camb. em duas populações de mata ciliar. Revista Árvore 2006; 30(5): 821-827. http://dx.doi.org/10.1590/ S0100-67622006000500016.

Carvalho PER. Espécies arbóreas Brasileiras. Colombo: Embrapa Florestas; 2003.

Earl DA, vonHoldt BM. STRUCTURE HARVESTER: a website and program for visualizing STRUCTURE output and implementing the Evanno method. Conservation Genetics Resources 2012; 4(2): 359-361. http://dx.doi. org/10.1007/s12686-011-9548-7.

Ellstrand NC, Elam DR. Consequences of small population size: Implications for plant conservation. Annual Review of Ecology and Systematics 1993; 24(1): 217-242. http:// dx.doi.org/10.1146/annurev.es.24.110193.001245.

Evanno G, Regnaut S, Goudet J. Detecting the number of clusters of individuals using the software STRUCTURE: A simulation study. Molecular Ecology 2005; 14(8): 26112620. http://dx.doi.org/10.1111/j.1365-294X.2005.02553.x. PMid:15969739.

Ferreira DK, Nazareno AG, Mantovani A, Bittencourt R, Sebbenn AM, Reis MS. Genetic analysis of 50-year old Brazilian pine (Araucaria angustifolia) plantations: implications for conservation planning. Conservation Genetics 2012; 13(2): 435-442. http://dx.doi.org/10.1007/ s10592-011-0296-8.

Fischer E, Santos FAM. Demography, phenology and sex of Calophyllum brasiliense (Clusiaceae) trees in the Atlantic forest. Journal of Tropical Ecology 2001; 17(6): 903-909. http://dx.doi.org/10.1017/S0266467401001675.

Galvão F, Roderjan CV, Kuniyoshi YS, Ziller SR. Composição florística e fitossociologia de caxetais do Litoral do Estado 
do Paraná - Brasil. Floresta 2002; 32(1): 17-39. http:// dx.doi.org/10.5380/rf.v32i1.2347.

Goudet J. FSTAT, a program to estimate and test gene diversities and fixation indices (version 2.9.3.2) [online]. 2002 [cited 2016 March 3]. Available from: http://www. unil.ch/izea/softwares/fstat.html

Hall P, Walker S, Bawa K. Effect of forest fragmentation on genetic diversity and mating system in a tropical tree. Conservation Biology 1996; 10(3): 757-768. http://dx.doi. org/10.1046/j.1523-1739.1996.10030757.x.

Hamrick JL, Godt MJW, Sherman-Broyles SL. Factors influencing levels of genetic diversity in woody plant species. New Forests 1992; 6(1-4): 95-124. http://dx.doi. org/10.1007/BF00120641.

Hamrick JL, Godt MJW. Allozyme diversity in plant species. In: Soltis D, Soltis P, editors. Isozymes in plant biology. Portland: Dioscorides Press; 1989.

Hmeljevski KV, Reis A, Montagna T, Reis MS. Genetic diversity, genetic drift and mixed mating system in small subpopulations of Dyckia ibiramensis, a rare endemic bromeliad from Southern Brazil. Conservation Genetics 2011; 12(3): 761-769. http://dx.doi.org/10.1007/s10592011-0183-3.

Kageyama PY, Gandara FB, Souza LMI. Consequências genéticas da fragmentação sobre populações de espécies arbóreas. Serie Tecnica 1998; 12(32): 65-70.

Kawaguici CB, Kageyama PY. Diversidade genética de três grupos de indivíduos (adultos, jovens e plântulas) de Calophyllum brasiliense em uma população de mata de galeria. Scientia Forestalis 2001;(59): 131-143.

Kephart SR. Starch gel electrophoresis of plant isozymes: a comparative analysis of techniques. American Journal of Botany 1990; 77(5): 693-712. http://dx.doi. org/10.1002/j.1537-2197.1990.tb14456.x.

Klein RM. Mapa Fitogeográfico do Estado de Santa Catarina. Itajaí: Herbário Barbosa Rodrigues; 1978.

Li CC. Population genetics. Chicago: University Chicago Press; 1976.

Lingner DV, Schorn LA, Vibrans AC, Meye RL, Sevegnani L, Gasper AL et al. Fitossociologia do componente arbóreo/ arbustivo da Floresta Ombrófila Densa em Santa Catarina. In: Vibrans AC, Sevegnani L, Lingner DV, Gasper AL, editores. Inventário florístico florestal de Santa Catarina. Vol. 4. Blumenau: Edifurb; 2013.

Mantel N. The detection of disease clustering and a generalized regression approach. Cancer Research 1967; 27(2 Part 1): 209-220. PMid:6018555.

Marques MCM, Joly CA. Germinação e crescimento de Calophyllum brasiliense (Clusiaceae), uma espécie típica de florestas inundadas. Acta Botanica Brasílica 2000; 14(1): 113-120. http://dx.doi.org/10.1590/S010233062000000100010 .
Marques MCM, Silva SM, Liebsch D. Coastal plain forests in southern and southeastern Brazil: ecological drivers, floristic patterns and conservation status. Brazilian Journal of Botany 2015; 38(1): 1-18. http://dx.doi.org/10.1007/ s40415-015-0132-3.

Nazareno AG, Reis MS. At risk of population decline? An ecological and genetic approach to the threatened palm species Butia eriospatha (Arecaceae) of southern brazil. The Journal of Heredity 2014; 105(1): 120-129. http://dx.doi.org/10.1093/jhered/est065. PMid:24078681.

Nei M. Analysis of gene diversity in subdivided populations. Proceedings of the National Academy of Sciences of the United States of America 1973; 70(12): 3321-3323. http:// dx.doi.org/10.1073/pnas.70.12.3321. PMid:4519626.

Oliveira VC, Joly CA. Flooding tolerance of Calophyllum brasiliense Camb. (Clusiaceae): Morphological, physiological and growth responses. Trees (Berlin) 2010; 24(1): 185-193. http://dx.doi.org/10.1007/s00468-009-0392-2.

Pritchard JK, Stephens M, Donnelly P. Inference of population structure using multilocus genotype data. Genetics 2000; 155(2): 945-959. PMid:10835412.

Reis CAF, Souza AM, Mendonça EG, Gonçalvez FR, Melo RMG, Carvalho D. Diversidade e estrutura genética espacial de Calophyllum brasiliense Camb. (Clusiaceae) em uma floresta paludosa. Revista Árvore 2009; 33(2): 265-275. http://dx.doi.org/10.1590/S0100-67622009000200008.

Reis MS, Mantovani A, Silva JZ, Mariot A, Bittencourt R, Nazareno AG et al. Distribuição da diversidade genética e conservação de espécies arbóreas em remanescentes florestais de Santa Catarina. In: Vibrans AC, Sevegnani L, Gasper AL, Lingner DV, editores. Inventário florístico florestal de Santa Catarina. Vol. 1. Blumenau: Edifurb; 2012.

Reitz R, Klein RM, Reis A. Projeto madeira de Santa Catarina. Sellowia 1978; 28-30: 11-320.

Rogalski JM, Reis A, Rogalski M, Montagna T, Reis MS. Mating system and genetic structure across all known populations of dyckia brevifolia: a clonal, endemic, and endangered rheophyte bromeliad. The Journal of Heredity 2017; 108(3): 299-307. http://dx.doi.org/10.1093/jhered/ esx011. PMid:28199659.

Rousset F. Genetic differentiation and estimation of gene flow from F-Statistics under isolation by distance. Genetics 1997; 145(4): 1219-1228. PMid:9093870.

Santa Catarina. Secretaria de Estado do Desenvolvimento Econômico Sustentável.Conselho Estadual do Meio Ambiente - CONSEMA. Resolução CONSEMA $n^{\circ}$ 51, de 05 de dezembro de 2014. Reconhece a Lista Oficial das Espécies da Flora Ameaçada de Extinção no Estado de Santa Catarina e dá outras providências. Diário Oficial do Estado de Santa Catarina [online]. Florianópolis, SC (2014 dez. 23): 1-11 [cited 2017 Febr 12]. Available from: http://www.sds.sc.gov.br/index.php/biblioteca/ consema/legislacao/resolucoes/325-resolucao-consemano-512014-1/file 
Scarano FR. Plant community structure and function in a swamp forest within the Atlantic Rain Forest complex: a synthesis. Rodriguésia 2006; 53(3): 491-502. http://dx.doi. org/10.1590/2175-7860200657308.

Schultz J. Calophyllum brasiliense. In: Coradin L, Reis A, Siminski A, editores. Espécies nativas da flora brasileira de valor econômico atual ou potencial: plantas para o futuro - Região Sul. Brasília: Ministério do Meio Ambiente; 2012.

Sebbenn AM. Número de árvores matrizes e conceitos genéticos na coleta de sementes para reflorestamentos com espécies nativas. Revista do Instituto Florestal 2002; 14(2): 115-132.

Silva JZ, Reis MS. Effects of different simulated management intensities on the genetic diversity of a heart-of-palm tree natural population (Euterpe edulis Martius). Silvae
Genetica 2010; 59(5): 201-210. http://dx.doi.org/10.1515/ sg-2010-0024.

Souza AM, Carvalho D, Vieira FA, Nascimento LH, Lima DC. Estrutura genética espacial de populações naturais de Calophyllum brasiliense Camb. em mata de galeria. Cerne 2007; 13(3): 239-247.

Templeton AR. Genética de populações e teoria microevolutiva. Ribeirão Preto: Sociedade Brasileira de Genética; 2011.

Vibrans AC, Gasper AL, Müller JJV, Reis MS. Introdução. In: Vibrans AC, Sevegnani L, Gasper AL, Lingner DV, editors. Inventário florístico florestal de Santa Catarina. Vol. 1. Blumenau: Edifurb; 2012.

Weir BS, Cockerham CC. Estimating F-Statistics for the analysis of population structure. Evolution; International Journal of Organic Evolution 1984; 38(6): 1358-1370. PMid:28563791. 